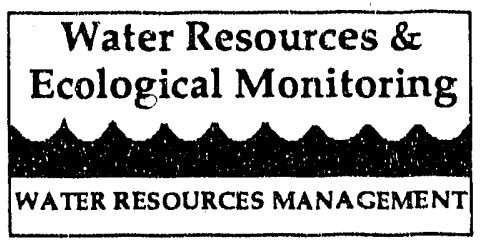

\title{
Status of Wheeler Reservoir
}

An Overview of Reservoir Conditions

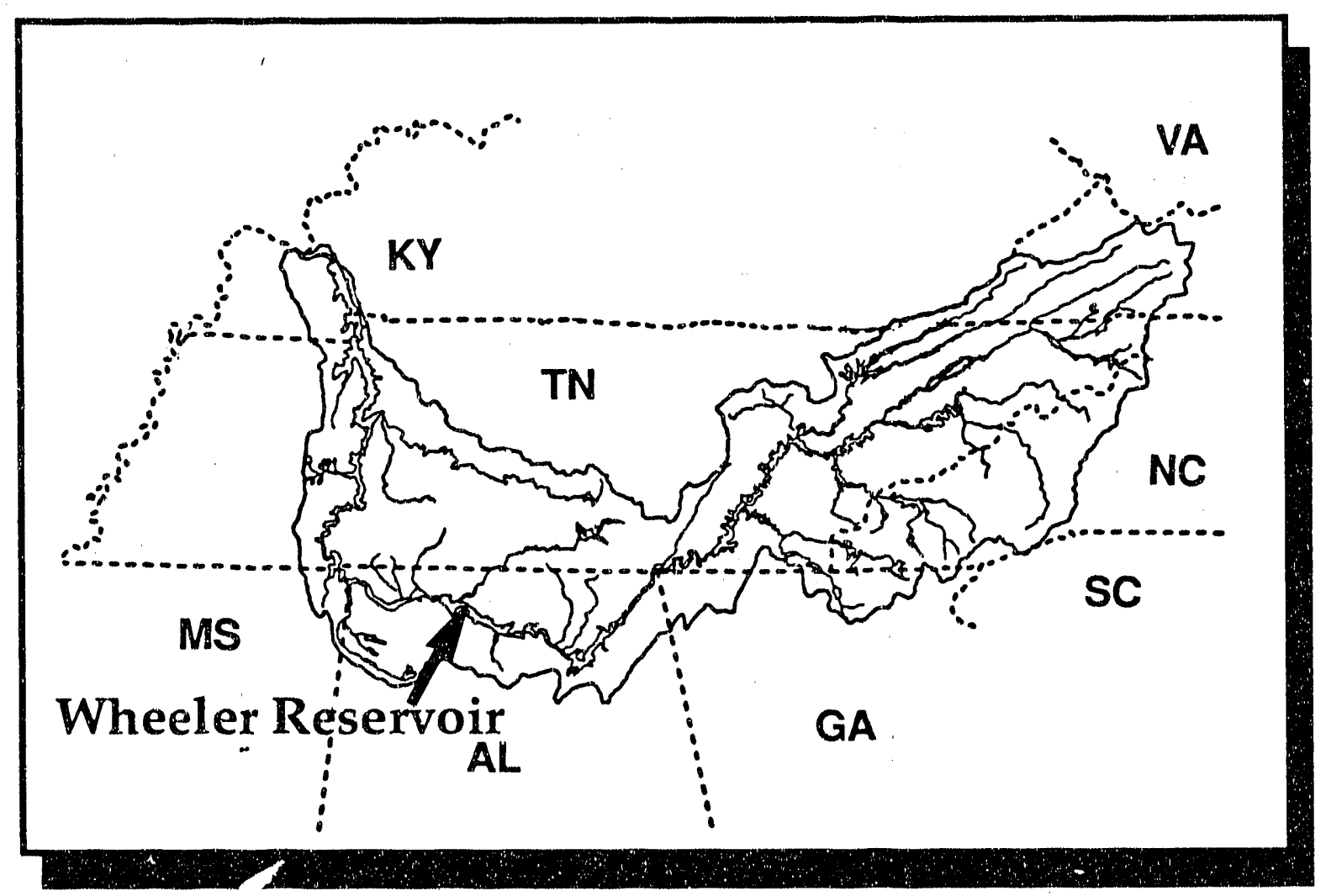

Tennessee Valley Authority

Resource Development

River Basin Operations

Water Resources Division

September 1990 


\section{CONTENTS}

\section{Page}

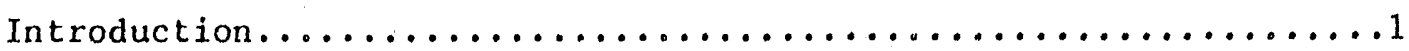

Purpose and Operation of Wheeler Dam and Reservoir...........3

Description of Watershed and Reservoir Area...............

Reservoir Characteristics and Uses.....................

Water Quality and Biological Conditions..................13

Conditions Affecting Reservoir Uses....................... . . 25

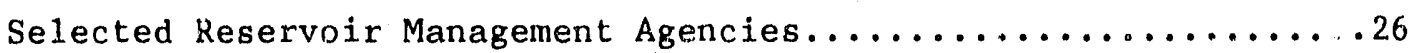

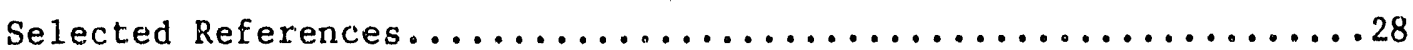

DSTRIBUTION OF THIS DOCUMENT IS UNLIMITER

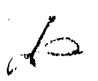

TVA/WR/WQ--90/20 


\section{INTRODUCTION}

This is one in a series of status reports prepared by the Tennessee Valley Authority. (TVA) for those interested in the conditions of TVA reservoirs. This overview of Wheeler Reservoir summarizes reservoir purposes and operation, reservoir and watershed characteristics, reservoir uses and use impairments, and water quality and aquatic biological conditions. The information presented here is from the most recent reports, publications, and original data available. If no recent data were available, historical data were summarized. If data were comnletely lacking, environmental professionals with special knowledge of the resource were interviewed.

Wheeler Reservoir provides man" public and private uses for the people of north Alabama and for overall regional economic growth and development. Operated primarily for flood control, navigation, and power generation, Wheeler Reservoir also supports other uses including shoreline development, water supply, recreation, aquatic and wildlife habitata, and sport fisheries.

Several conditions limit uses of Wheeler Reservoir. Colonization of the reservoir with aquatic plants affects industrial water supply, boating, shoreline use, aesthetic quality of the environment, and power production. The associated mosquito populations are also a nuisance. Contamination of fish from Wheeler Reservoir with the pesticide DDT has affected the comercial fishery and may detract from the sport fishing experience for some users. Concentrations of fecal coliform bacteria and the presence of wastewater discharges male some areas of the reservoir unsuitable for swimming and other water contact recreation. In addition, the oxygen demand of discharged wastewaters sometimes lowers the dissolved oxygen concentration of the reservoir to below desirable levels. In turn, the naturally high water temperature of the reservoir during the summer constrains industrial discharges of cooling water. 
The sauger population of Wheeler Reservoir has declined significantly in recent years, possibly because of the impact of several years of drought conditions. Large populations of mussels once present in the reservoir have been largely depleted by commercial harvesting.

Several agencies have a part in improving and protecting the beneficial uses of Wheeler Reservoir including TVA, the Alabama Department of Environmental Management, and the Alabama Departinent of Conservation and Natural Resources. These agencies investigate and monitor the reservoir and attempt to mitigate those conditions impairing its uses. 
Wheeler Reservoir was formed on the Tennessee River in north Alabama with the closing of TVA's Wheeler Dam in 1936. In accordance with the purposes established by the TVA Act, TVA operates the dam for navigation, flood control, and, to the extent consistent with these primary purposes, for power production.

Normal operation for flood control involves starting reservoir filling by March 15 to reach full pool (elevation 556 feet above mean sea level (msl) by Apri1 15, and starting drawdown July 1 to reach normal winter operating range (elevation 550-55\%. feet ms 1 ) by late fa11. To provide a navigable channel depth of at least eleven feet, the winter pool elevation is kept at el. 550 or above, unless sufficient releases are being made from Guntersville Dam to provide minimum depth in the upper reaches of Wheeler Reservoir.

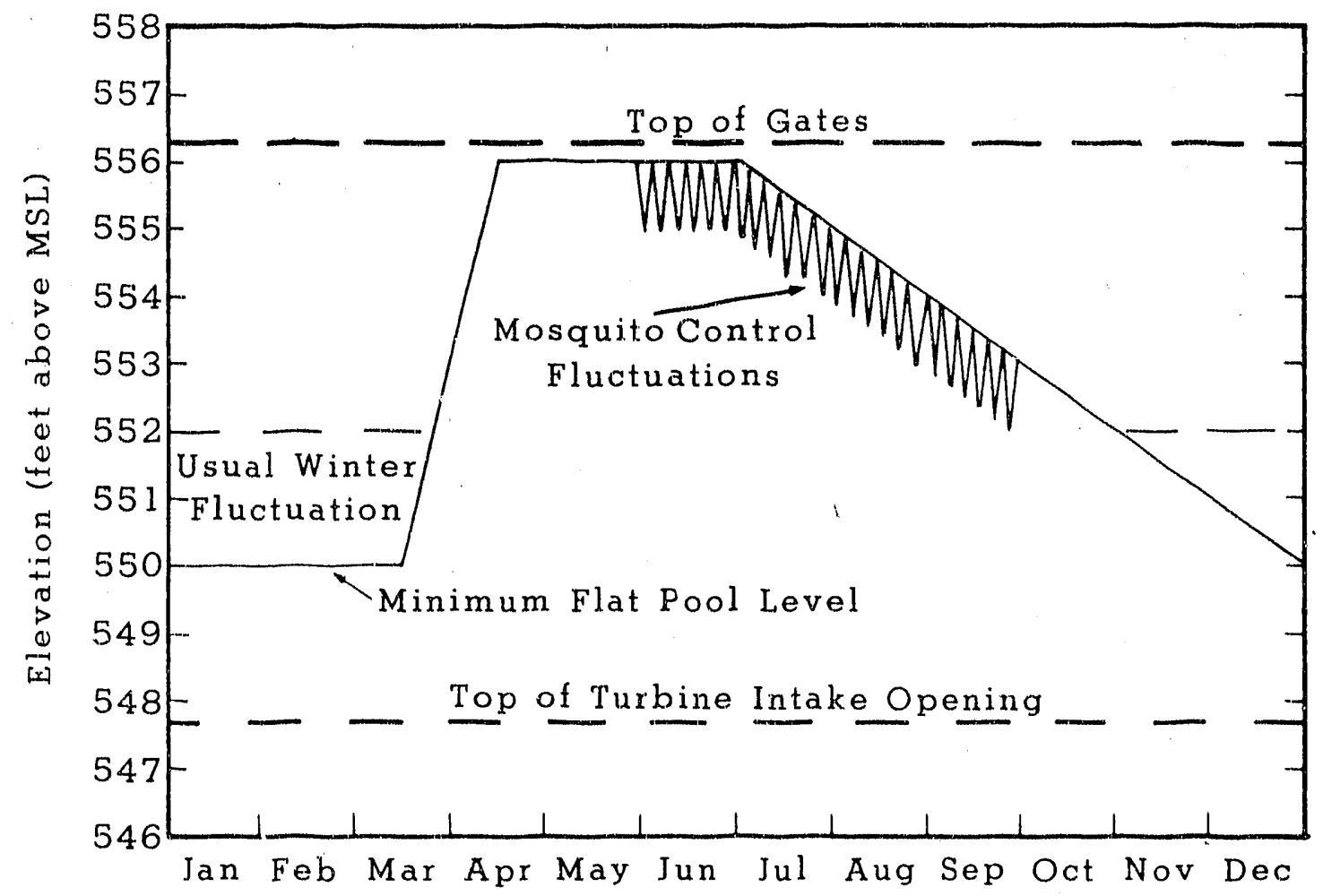

Annual Operating Curve of Wheeler Reservoir 
After navigation and flood control constraints are met, Wheeler Dam is operated to meet power system demands as economically as possible. Because hydropower generation is the most economical, versatile, and dependable power source in the TVA system, it is used to provide peaking power quick1y for those times of day when power demands are highest. Hydropover generation is also scheduled for high demand times of the week (generally during the 5-day workweek) and high demand times of the year (June through August and December through February), depending on the availability of water from upstream regulation.

When consistent with the three primary purposes of flood control, navigation, and power production, water levels in Wheeler Reservoir are regulated to benefit other uses. In recent years, full pool has been maintained through July for two of every three years to provide enhanced levels consistent with reservoir maintenance activities including rebrushing. Every third year, drawdown is begun earlier to allow for mowing of shoreline vegetation to assist in mosquito control. Between mid-May and mid-September, water levels are fluctuated for mosquito control by raising and lowering pool elevation about one foot on a weekly cycle. 
DESCRIPTION OF' WATERSHED AND RESERVOIR AREA

Watershed Characteristics

Wheeler Reservoir receives drainage from a total of 29,590 square miles; only $5,1.40$ square miles of that total is downstream of Guntersville Dam. The largest tributary to Wheeler Reservoir, the E1k River, has a total drainage area of 2,249 square miles. The next largest tributaries are Flint River, Paint Rock River, and Flint Creek, with drainage areas of 568,458 , and 455 square miles, respectively.

The watershed is primarily mixed hardwood forests and farms, many on prime farmland. The floodplain zones of Wheeler Reservoir also support. many areas of bottomland hardwood forest that provide important wildlife habitat. This habitat is especially important because such wetlands are rapidly being lost to clearing for agriculture.

Cotton and soybeans are the most important crops in the area, and some of the subwatersheds draining to Wheeler Reservoix are the most intensively row-cropped land in the state. Cropland erosion rates in the counties bordering Wheeler Reservoir range from 11 to 30 percent above the state average, and about 40 percent of the cropland in the area is eroding at a rate greater than twice the soil loss tolerance (the maximum rate of erosion that will permit high level production economically and indefinitely). Because of these high erosion rates and the extensive use of pesticides and fertilizer on intensively row-cropped lands, the Tennessee River watershed has been identified by several sources as especially prone to water quality degradation from agricultural nonpoint sources. Several tributaries to Wheeler Reservoir are known to be affected by cropland erosion, including Piney Creek, Limestone Creek, F1int River, Beaverdam Creek, Round Island Creek, Swan Creek, Flat Creek, and Paint Rock River (Cox 1910).

Several counties bordering Wheeler Reservoir rank in the top ten counties in Alabama in production of dairy and beef cattle, hogs and pigs, broiler chickens, and eggs. Several tributaries to the reservoir 
have been identified as affected by runoff of animal waste, including Piney Creek, Limestone Creek, F1int River, Round Island Creek, Flint. Creek, and Flat Creek.

Over one-half milion people live in the counties surrounding Wheeler Reservoir. The most populated area, Huntsville/Madison County, is expected to grow from 242,700 to 275,000 by 1995 . The Decatur/Morgan County area is the second most populated with 98,000 residents and an expected growth to 99,000 by 1995 . The remaining five counties adjoining the reservoir have a total population of 170,000 .

\section{Shoreline Characteristics}

There are 1,063 miles of shoreline around wheeler Reservoir. Of 115 miles of privately owned shoreline, 43 miles are developed. The upstream third of Wheeler Reservoir shoreline is mostly composed of tracts sold by TVA that have remained undeveloped and narrow strips of undereloped TVA property. Developments in the area include the U. S. Army's Redstone Arsenal and Huntsville's marina and public use area. Huntsville is about. 10 miles north of the river near Tennessee River mile (TRM) 333. The Redstone Arsenal complex occupies most of the north bank from TRM 332 downstream to about TRM 321. Decatur and its large waterfront industrial complex stretch along the south bank from about TRM 309 to TRM 298, and TVA's Browns Ferry Nuclear Plant (BFN) is located on the north bank at TRM 294.0. Wheeler National Wild1ife Refuge, a 34,000-acre wintering ground for migratory waterfow1, occupies both sides of roughly the middle third of Wheeler Reservoir east of Decatur (from TRM 305 to TR' 324). The westernmost edge of the refuge is within the city limits of Decatur, and its easternmost edge borders the city limits of Huntsville. Two state wildlife management areas are also located near Decatur. Private residential development has occurred along the lower portion of the reservoir and in the E1k River area. Joe Wheeler State Park (1939 acres) is located at both ends of the dam. The remaining downstream reservoir shoreline has either been sold or is retained by TVA in forestry or agricultural production. 


\section{Physical Characteristics}

of the nine mainstem Tennessee River reservoirs, Wheeler Reservoir ranks third in area and fourth in volume. The main channel of Wheeler Reservoir varies from 20 to 50 feet deep. Throughout much of the length of the reservoir, the main channel is bound by shallow overbank areas (floodplain inundated when the reservoir was impounded); consequently, about half of the reservoir area is less than 15 feet deep. Additional physical features of Wheeler Reservoir are summarized below.

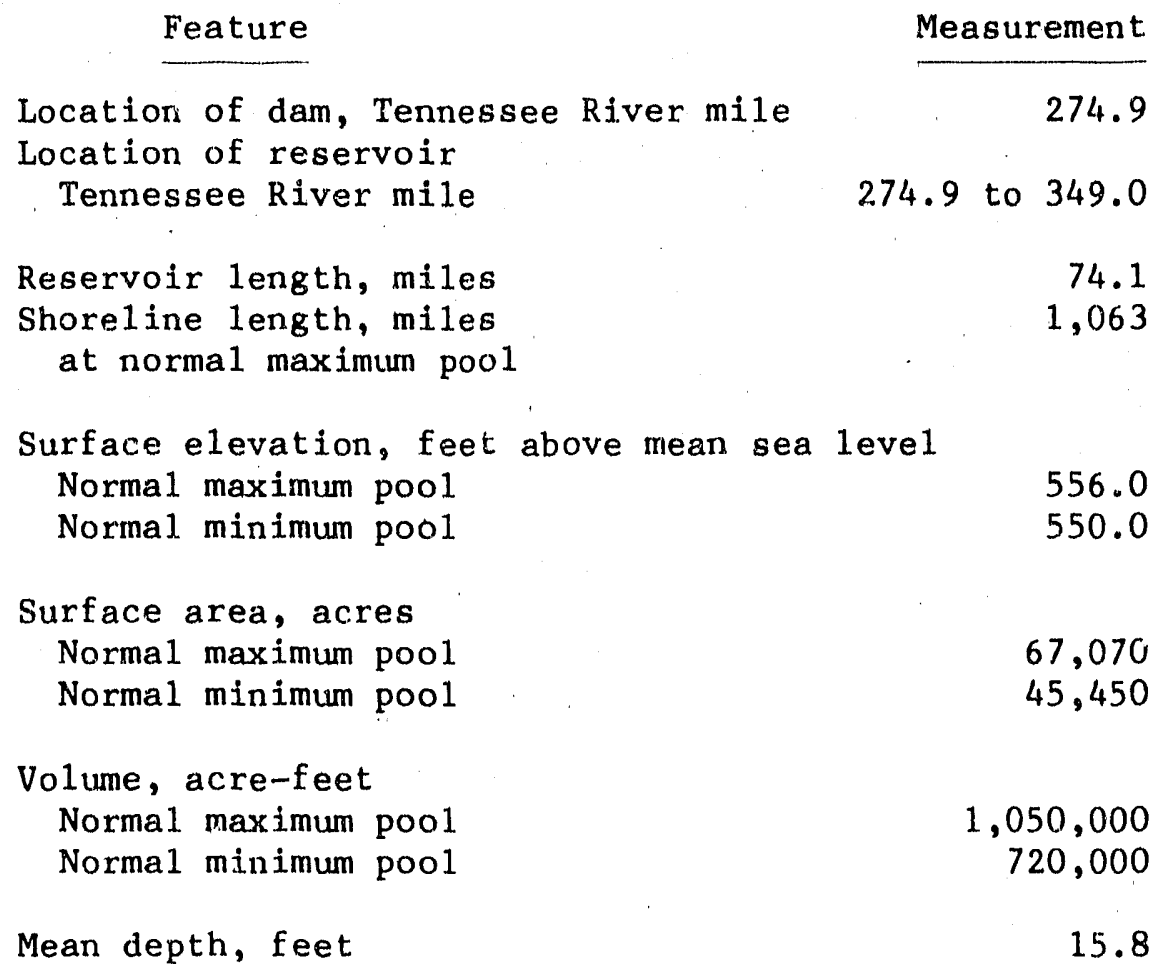

\section{Hydrologic Characteristics}

Average month1y discharges from Wheeler Dam vary from a high of $78,000 \mathrm{ft}^{3} / \mathrm{sec}$ in March to a low of $32,400 \mathrm{ft}^{3} / \mathrm{sec}$ in September, with an estimated annual average flow of $49,500 \mathrm{ft}^{3} / \mathrm{sec}$. On average, the entire volume of Wheeler Reservoir is renewed every nine days. On annual average, 83 percent of the total inflow of Wheeler Reservoir originates from discharges from Guntersville Dam and 17 percent originates from local tributaries (primarily the E1k River). Guntersville's average 
contribution to the total inflow to wheeler varies seasonally from a low of 74 percent in March to a high of 90 percent in September.

Uses of Wheeler Reservoir

The Alabama Department of Environmental Management (ADEM) ha assigned use classifications to Wheeler Reservoir and its tributaries that determine the water quality criteria that applied when making management decisions such as issuing permits for the discharge of wastewater.

ADEM classifies the Tennessee River for use as a public water supply from Wheeler Dam to the Elk River, from U.S. Highway 31 to Flint Creek, and from Cotaco Creek to the Flint River. Except for the immediate vicinity of the discharge from Decatur's sewage treatment plant and the reach $f$ rom Indian Creek to Flint River, the Tennessee river from Wheeler Dam to Guntersville Dam is classified as suitable for swimming and other whole body water-contact sports. The entire reservoir and most of its tributaries are classified as suitable for fish and wildlife.

In accordance with the TVA Act, TVA operates Wheeler Reservoir for the primary purposes of navigation, flood control, and hydroelectric generation. However, Wheeler Reservoix supports many secondary benefits such as shoreline development, recreation, wastewater assimilation, habitat for biological communities, and sport and comercial fishing, in addition to the uses designated by ADEM.

\section{Navigation}

Wheeler Dam has two navigation locks. Barge traffic on Wheeler Reservoir increased from 6.6 million tons in 1970 to 9.5 million tons in 1986. Important tonnage included grains and grain products, coal and coke, and chemicals. Recent increases in tonnage are partly the result of opening of the Tennessee-Tombigbee Waterway in January 1985. Further increases are predicted over the next few years because the waterway provides a direct connection between the Port of Mobile, the Tennessee River, and 16,000 miles of inland navigable waterways. 
Power Production

Wheelex Dam has 11 hydropower units with a total capacity of 378 megawatts, which is 11 percent of the total hydrogenerating capacity of the TVA reservoir system.

\section{F1ood Control}

Wheeler Reservoir provides 349,000 acre-feet of flood storage capacity--about three percent of the total flood storage capacity for the TVA reservoir system.

\section{Public Water Supply}

The four municipal water supply intakes located on Wheeler Reservoix are listed below. Their average daily use totals about 43 million gallons. In many cases, the municipal systems also supply potable and process water to nearby industries.

$\begin{array}{ll}\begin{array}{l}\text { Water supply } \\ \text { Decatur, Alabama }\end{array} & \frac{\text { Intake location }}{\text { Northeast Morgan County }} \\ \begin{array}{l}\text { Water and Fire Protection Authority } 306.0 \\ \text { Huntsville, Alabama }\end{array} & \text { TRM } 331.1 \\ \text { TRMs } 319.4 \text { and } 334.2\end{array}$

\section{Industrial Water Supply}

The nine industrial water supply intakes located on Wheeler Reservoir are listed below. Excluding the water used to generate hydropower at Wheeler Dam, their average daily use totals over 800 million gallons.

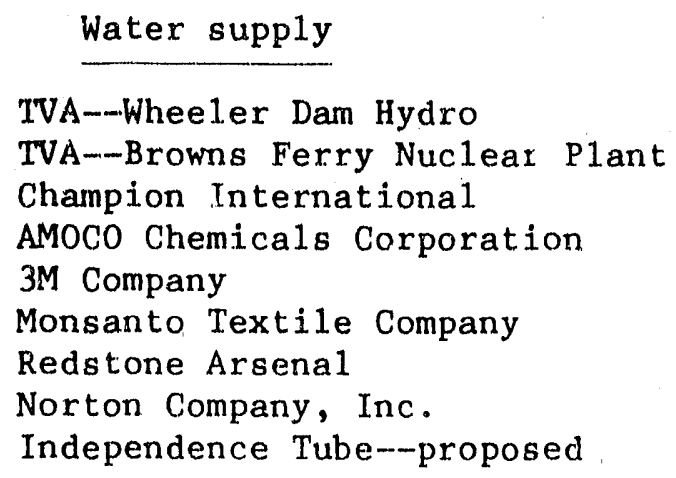

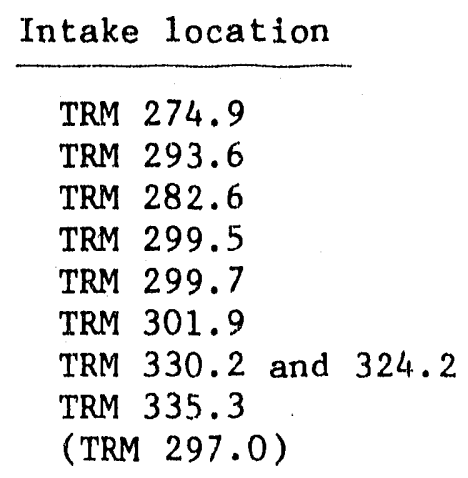


Agricultural Water Supply

The two agricultural water supplies on Wheeler Reservoir are 1isted below. Their average daily use totals less than one million gallons.

$\begin{array}{lc}\frac{\text { Water supply }}{\text { Joe Wheeler State Park }} & \text { Intake location } \\ \begin{array}{l}\text { City of Decatur--Point Mallard } \\ \text { Park Golf Course }\end{array} & \text { TRM } 278.5\end{array}$

Wastewater Assimilation

Most treatment plants for municipal and domestic wastewater in the Wheeler Reservoir area are small facilities that discharge to tributary streams rather than directly to the reservoir. The major (more than one million gallons per day) municipal and industrial wastewater discharges into Wheeler Reservoir are listed below.

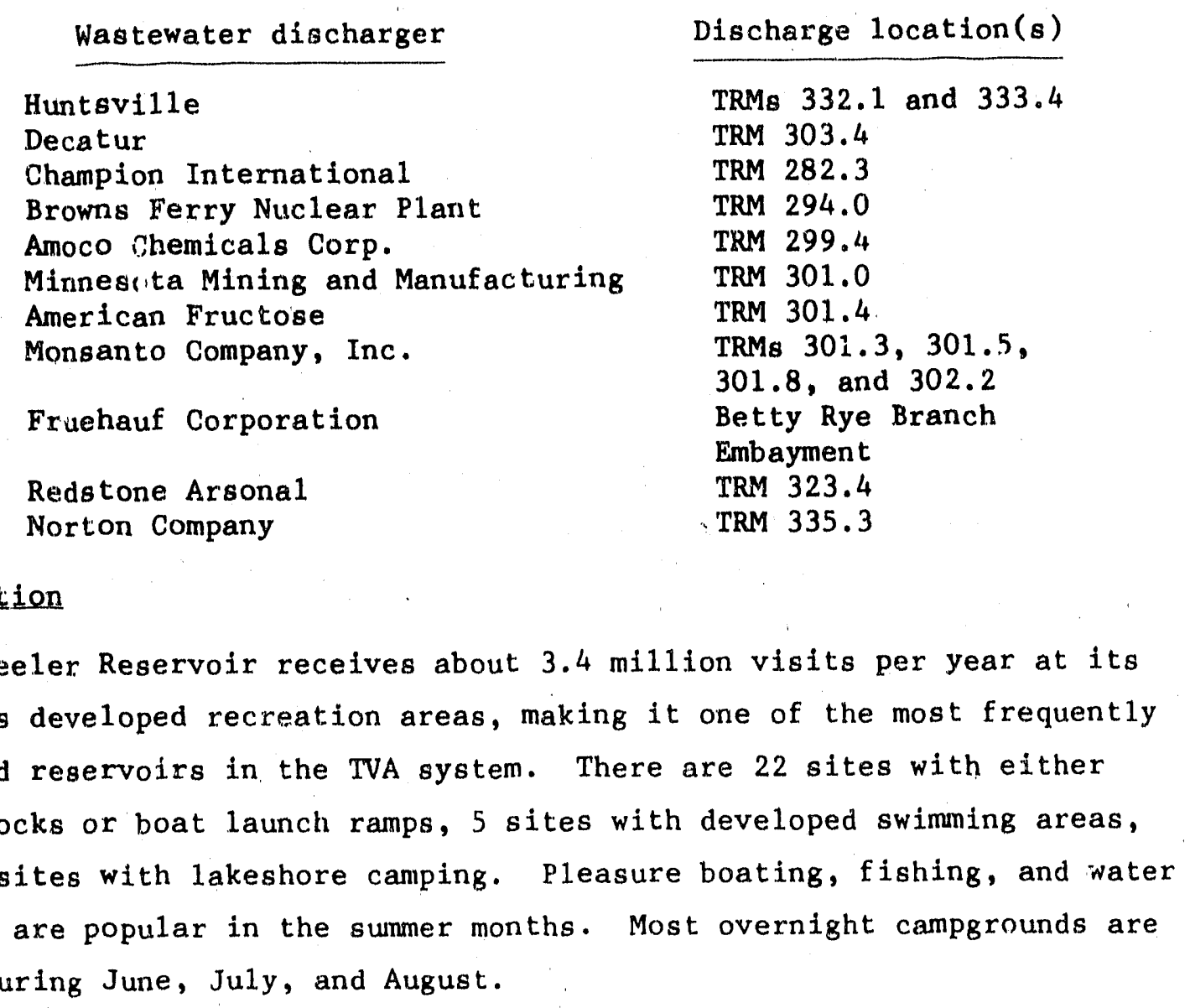


The reservoir is open to sport fishing year-round, subject to state regulations. The principal sport species harvested are crappie, largemcuth and smallmouth bass, sunfish (mostly bluegill and redear), white and yellow bass, and sauger. The estimated annual sport fish harvest on Wheeler Reservoir is 188,000 pounds taken during 100,000-120,000 sport fishing trips. The value of this sport fishery to the local economy is estimated to be between $\$ 11,500,000$ and $\$ 13,000,000$ per year.

\section{Support For Biojegical Communities}

Wheeler Reseivoix provides habitat for a varitty of aquatic organisms and wildife. Sereral aquatic organisms are threatened or endangered and have state or federal protected status. Four endangered mussel species are present in the reservoir (pink mucket, orange-foot pimpleback, rough pigtoe, and fanshe11). A single threatened fish species, the snail darter, may occur in the Paint Rock River region of the reservoir. An amphibian (eastern kellbender) and the American alligator are the only other aquatic species of protected status known to occur in the reservoir. Peregrine falcons, listed as threatened by Alabama and endangered federally, feed primarily on waterfow 1 and shorebirds as they pass through wheeler National Wildlife Refuge during migration. The endangered gray bat, which feeds over water, occurs in caves in the Wheeler Reservoir area. Also, a small population of bald eagles, federally listed as endangered, spends the winter in the area. Recent efforts to hack baid eagles and osprey in north Alabama may eventually result in reproducing populations of these species on Wheeler Reservoir.

\section{Human Consumption of Aquatic Life and Wildife}

TVA does not have any numerical estimates on the amount of $f$ ish consumed, but Wheeler Reservoir has a popular sport fishery and a significant intrastate commercial fishery. 
Commercial Fishing

Wheeler Reservoir supports an extensive commercial fishery. The istimated annual commercial harvest is $1,400,000$ pounds, comprised mostly of buffalo ( 932,000 pounds) and catfish (468,000 pounds). Carp, gar, redhorse, drum, and paddlefish are also marketed. The total value of the annual $\mathrm{fish}$ harvest from Wheeler Reservoir is estimated to be $\$ 510,000$, about one-sixth of the total for all TVA reservoirs.

The mussel harvest on Wheeler Reservoir is limited. Habitat of mussels native to the Tennessee River has been altered by impoundment except in the Guntersville Dam tailwater (the portion of Wheeler Reservoir directly downstream of Guntersville Dam). Although the annual mussel harvest from Wheeler Reservoir was 4,800 tons in 1953, the harvest. is now probably less than 80 tons, with an approximate value of $\$ 80,000$ to $\$ 95,000$ (depending on she11 quality). Various sources have attriiuted the decline of the mussel fishery to high rate of exploitation, unfavorable environmental conditions, sediment effects, and industrial wastes.

\section{Shoreline Usage}

Mucl, of the Wheeler Reservoir shoreline is used by municipalities, industries, and farms. Residential development is important along the lower end of the reservoir. The presence of Wheeler National Wildlife Refuge on either side of the middle third of Witeeler Reservoir significantly limits increased use of the shoreline for residential and commercial development. Numerous sites along the resexvoir support water-oriented recreation, including marina areas with boat docks and ramps, swimming areas, lakeshore camping areas, and other pub1ic access areas (see centerfold map). 
WATER QUALITY AND BIOLOGICAL CONDITIONS

\section{Temperature and Dissolved Oxygen}

Wheeler Reservoir behaves less like a lake than like a large river: the rapid movement of water through the system usually keeps the reservoir relatively well mixed from surface to bottom. Depending on flow rates and weather conditions, surface temperatures in wheeler Reservoir are sometimes as much as $10^{\circ} \mathrm{F}$, warmer than temperatures at the bottom, but these periods are usually short (hours or a few days). Natura11y occurring surface water temperatures during the summer sometimes exceed Alabama's water quality criterion of $86^{\circ} \mathrm{F}$ (maximum) established for protection of sauger populations. This can pose a problem for industries that discharge heated water; cooling towers may be required to comply with water quality criteria.

Although Wheeler Reservoir does not have consistent or strong thermal stratification to inhibit mixing, concentrations of dissolved oxygen are usually higher at the surface than deeper in the water column. Part of this dissolved oxygen gradient arises from oxygen production during photosynihesis by algae in the sunlit surface waters. Algal photosynthesis sometimes leads to supersaturation with oxygen in the surface waters. Deeper in the water column, however, where there is no sunlight to support algal photosynthesis, dissolved oxygen concentrations are decreased by decay of naturally occurring organic matter and oxygen-demanding wastes discharged by municipalities and industries. The difierence between dissolved oxygen concentrations in surface water and deep water tends to be largest in embaynents (where tributaries enter the main body of the reservoir). Directly over the sediments in the summer, dissolved oxygen concentrations are 1 milligram per liter (mg/1) or less both in embayments and in the main channel.

At some times during the summer and fall (when warm water temperature speeds up the rate of oxygen removin by microbial activity and limits the amount of oxygen that will dissolve in the water), oxygen diffusion from the atmosphere into the reservoir and oxygen production by algal 


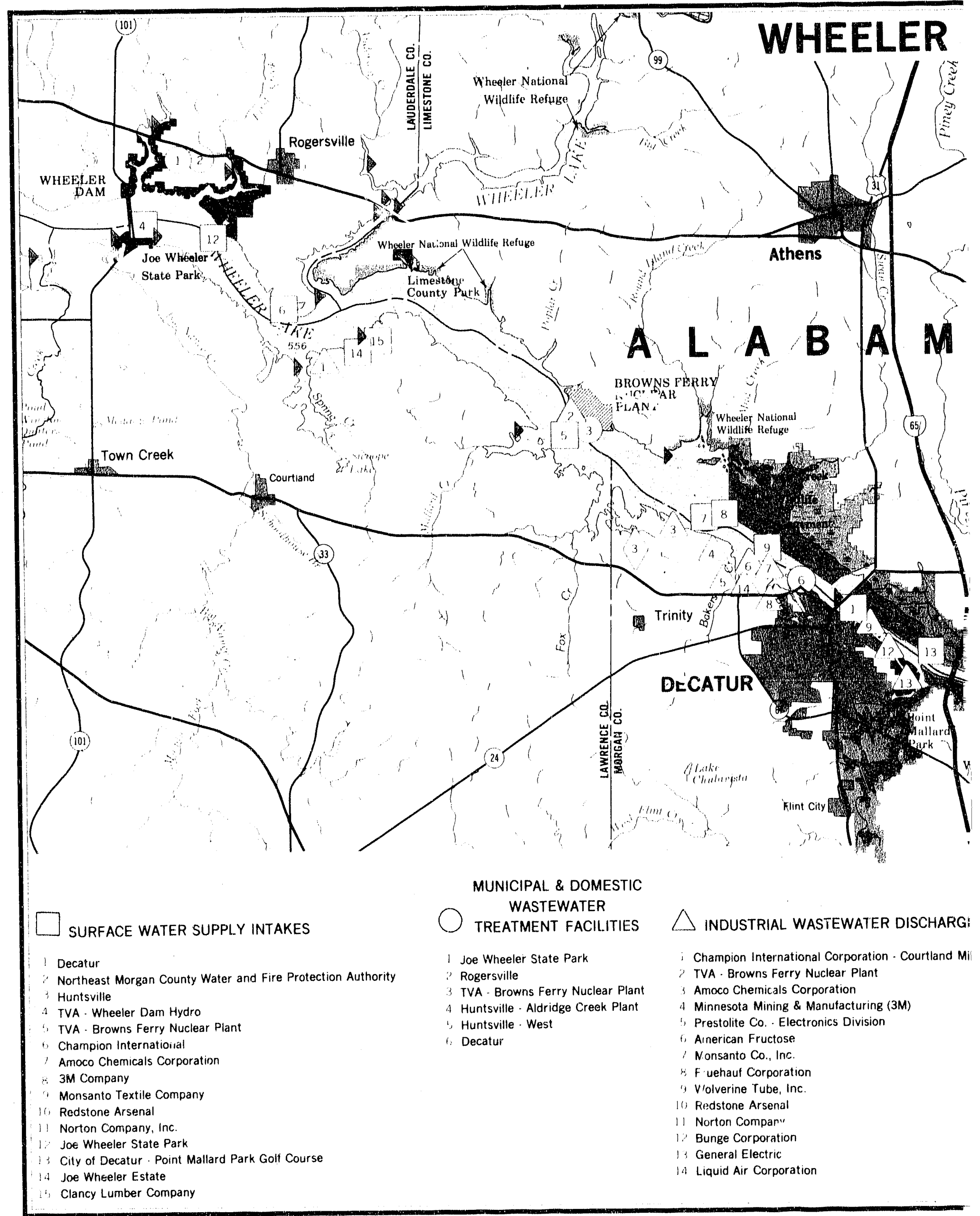




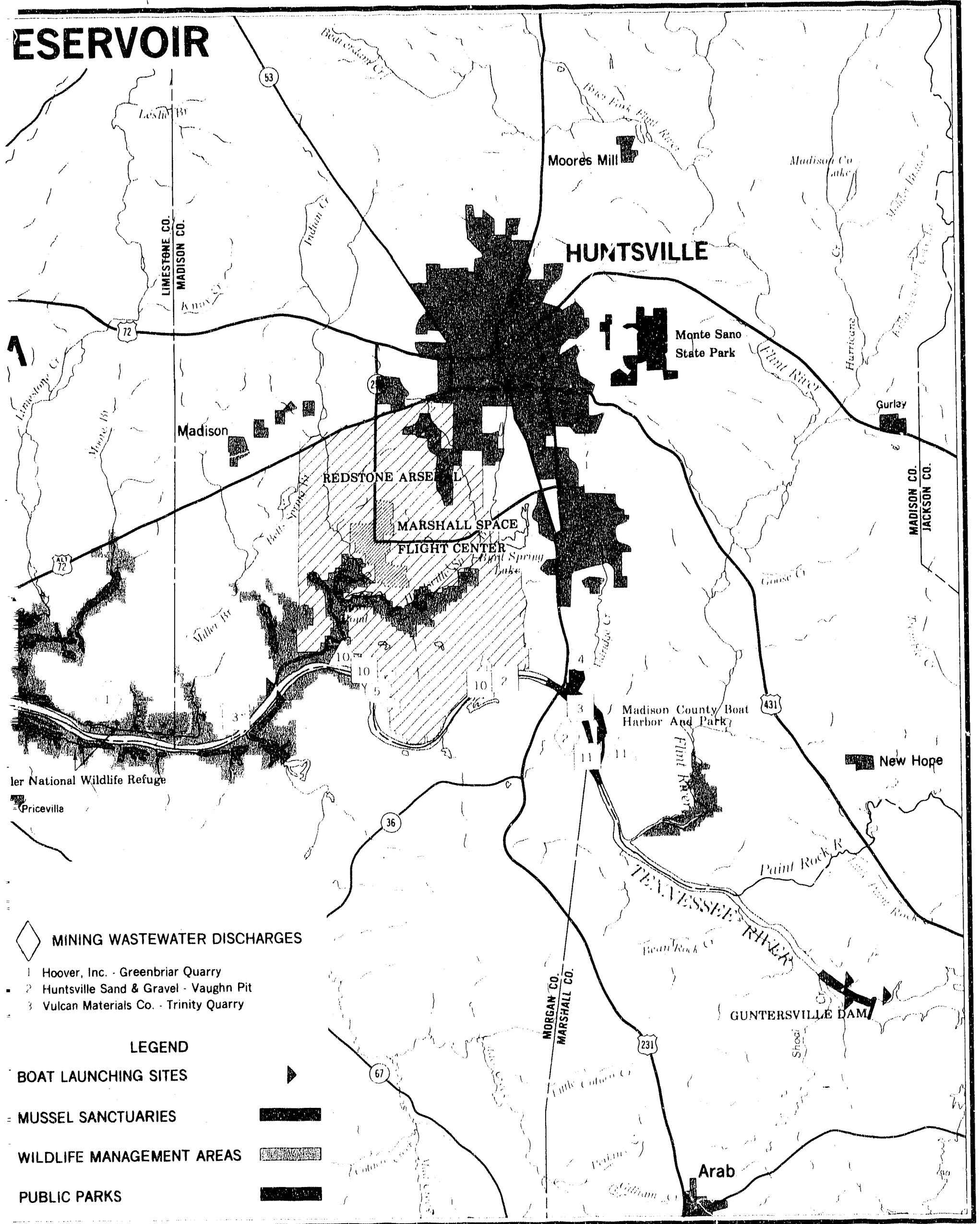


photosynthesis are not rapid enough to prevent dissolved oxygen concentrations near the surface from declining to near $5 \mathrm{mg} / 1$--the Alabama water quality criterion. The average 5-day biochemical oxygen demand $\left(\mathrm{BOD}_{5}\right)$, a measure of the amount of oxygen that would be used over a five-day period by bacteria degrading the organic material in the water) is about $2 \mathrm{mg} / 1$.

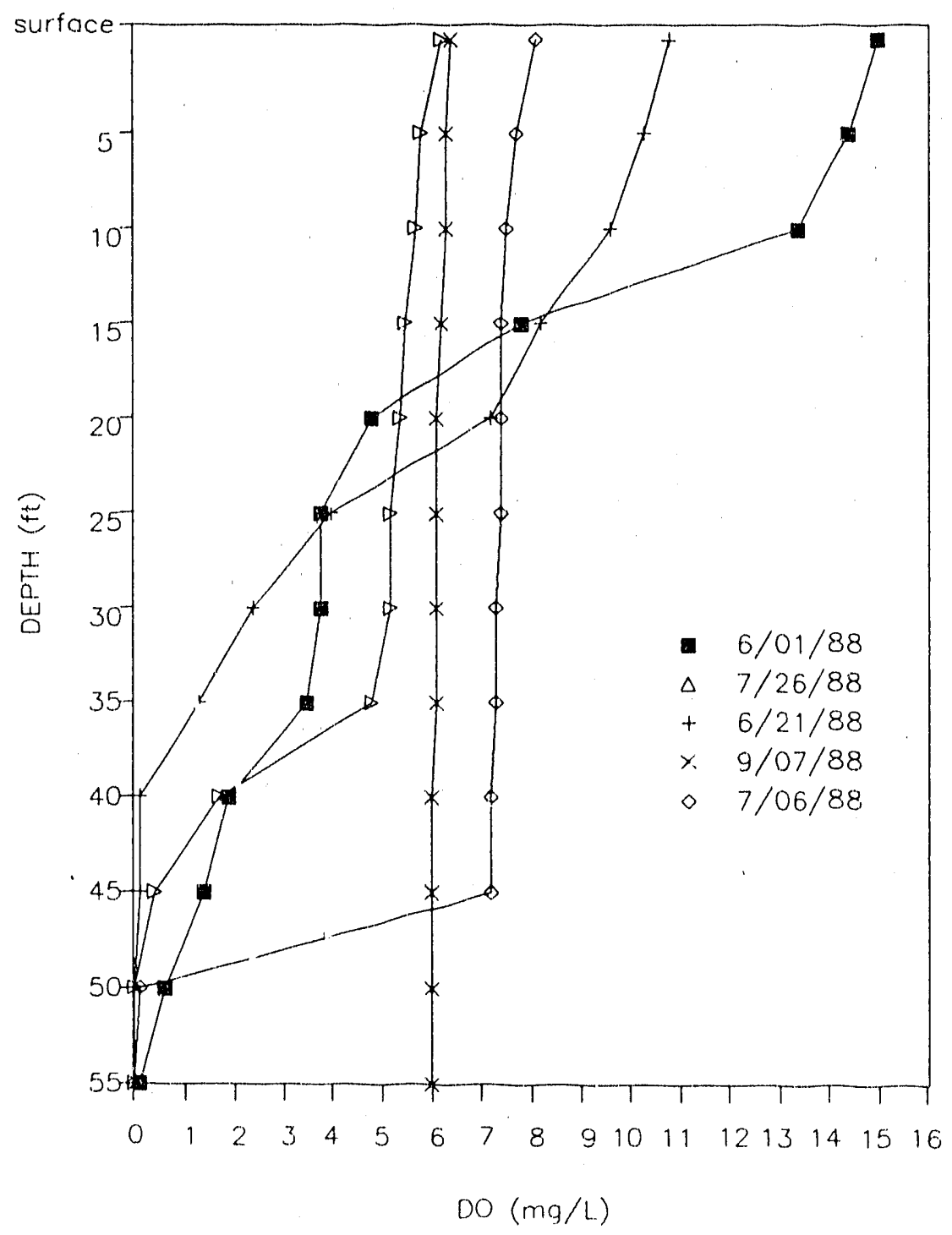

Dissolved oxygen profile in Wheeler Reservoir forebay (Tennessee River mile 2.75.1) in 1988

The turbines in Wheeler Dam withdraw water from essentially the entire depth of the forebay; therefore, the discharge consists of a 
mixture of oxygenated surface water and deoxygenated deep water. The dissolved oxygen concentration in discharges from Wheeler Reservoir is usually less than $5 \mathrm{mg} / 1$ for about four or five weeks each summer. The minimum dissolved oxygen concentration of the reservoir discharge varies from year to year.

\section{Water Clarity}

Secchi depth (a measure of the transparency of the water) is usually less than 2 meters, and total nonfilterable solids (a measure of suspended materials in the water) averages $10 \mathrm{mg} / 1$. Light penetration is temporarily reduced even further following rainfall, when tributary streams carry in a load of eroded soil and silt. These conditions are comparable to those in other IVA mainstem reservoirs. Nieasurements of true color in Wheeler Reservoir waters indicate levels that would be barely noticeable to a casual observer but that could require special treatment before some sensitive industrial uses, like textile production and food processing.

\section{Chemica1 Characteristics}

Wheeler Reservoir waters range from slight1y soft to moderately hard, and they are well buffered to a typical pH of 7.5. Higher $\mathrm{pH}$ values (greater than 9.0) occur occasionally near the surface and are probably due to the photosynthetic activity of algae and aquatic macrophytes.

Concentrations of lead and copper in Wheeler Reservoir sometimes exceed Alabama's water quality criteria for protection of aquatic life from toxicity. However, because the available metals data are for total concentrations-including not only the dissolved portion avallable for uptake by aquatic organisms but also the portion adsorbed to suspended matter-values that exceed these criteria do not necessarily indicate that aquatic life is being affected. Concentrations of lead and copper in fish from Wheeler Reservoir are comparable to concentrations in $\mathrm{f}$ ish from other TVA reservoirs and are not a concern for either public health or aquatic 1 ife. 


\section{Radiologic Characteristics}

As part of the operation of Browns Ferry Nuclear Plant, TVA routinely monitors radioactivity levels in reservoir water, commercial and game fish tissue, tissue from the asiatic clam Corbicula, and bottom sediments. All radioactivity levels have been consistent with naturally occurring or "background" levels or have been too low to be of consequence.

\section{Bacteriological Water Quality}

IVA investigated bacteriological water quality at recreation areas in Wheeler Reservoir in 1986 and again in 1990. Al1 sites in the main body of the reservoir complied with the Alabama water quality criterion (geometric mean of 10 samples must be less than 200 fecal coliform bacteria per 100 milliliters). The occasional high yalues (greater than 1,000 fecal coliforms per $100 \mathrm{~m} 1$ ) noted in some individual samples, especially following rainfall, indicate that the bacteriological quality of the reservoir is vulnerable to nonpoint sources of pollution such as runoff from livestock areas and failure of septic tants along the reservoir shoreline.

\section{Plankton}

Diverse communities of both phytoplankton (microscopic algae) and zooplankton (microscopic animals) occur in Wheeler Reservoir. These floating organisms are normally transported through wheeler Reservoir in one to two weeks. Wheeler Reservoir is typical of other mainstream reservoirs in that productivity and abundance of phytoplankton and zooplankton generally increase in pooled downstream areas where water movement is slower.

\section{Trophic State}

Eutrophication (enrichment) in the TVA mainstem reservoirs results in abundant colonization by large aquatic plants and floating algal mats along shorelines, and in abundant phytoplankton in the main body of the reservoir. The supply of the plant nutrients nitrogen and phosphorus 
exceeds demand in wheeler Reservoix. Total nitrogen concentrations are typically in the range of 0.5 to $0.6 \mathrm{mg} / 1$, and total phosphorus concentrations are typically 0.03 to $0.04 \mathrm{mg} / 1$. Growth of aquatic vegetation in Wheeler Reservoir is believed to be limited primarily by shallow sunlight penetration into the water, availability of suitable bottom substrata for anchorage of plant roots, fluctuations of pool elevation, and application of herbicides.

\section{Aquatic Plants}

Aquatic plant colonization in Wheeler, Reservoir has fluctuatid substantially over the last ten years. From 1.979 to 1988 , the number of acres colonized increased from 100 to 9,843 . For the most part, this pattern of increase results from the fact that most of these plants are not native to the Tennessee Jalley and therefore are not subject to the natural control mechanisms that limit populations of native species in TVA reservoirs. Drought conditions between 1984 and 1988 brought lower flows and increased water clarity that also markedly accelera'ed colonization. As of 1989, however, only 5,991 acres (a decline of 39 percent from 1988) were colonized. This decline is believed to be the result of flood conditions during the spring and summer of 1989. Present1y, Wheeler Reservoir ranks second among TVA reservoirs in terms of number of acres colonized and fourth in terms of the percentaze of the reservoir surface, area colonized.

Most of the aquatic plant colonization is between TRMs 293 and 310 , and in the Spring Creek and Flint Creek embayments. The predominant species is Eurasian watermilfoil. Colonies of hydrilla were discovered in Wheelex Reservoir in 1987 and now cover 266 acres, primarily around Decatur. The successful establishment of this aggressive and prolific plant may lead to more serious and frequent interference with reservoir uses in the future for several reasons: (1) hydrilla can colonize deeper areas than most of the other species found in the TVA system, (2) hydrilla is more difficult to control than many of the other species, and (3) hydrilla colonies tend to be very dense and can severely impede boat traffic and other recreation. 
The objective of TVA's Aquatic Plant Management Program is to minimize impacts on other desirable reservoir uses. Complete eradication of aquatic plant colonization is not feasible or desirable becau e this vegetation is important feeding habitat for many species of migrant-wintering waterfow 1 and provides cov, $f$ for game and forage $f i s h$. Aquatic plant management activities on Wheeler Reservoir include water level manipulation and herbicide treatment at high priority areas. Winter pool drawdown for flood control benefits aquatic plant management by exposing plant colonies to freezing and drying, Herbicides (primarily $2,4-D)$ are used in priority areas, generally around industrial intakes and along developed shorelines with high recreational usage.

\section{Mosquitoes}

Because the primary habitat for larval mosquito incubation is surface mats of aquatic plants, mosquito ;roduction has increased measurably over the last several years. Compared to other TVA reservoirs, Wheeler ranks about third in severity of mosquito problems. TVA has an active mosquito abatement program.

\section{Benthic Organisms}

The benthic community (bottom-dwelling organisms) in Wheeler Reservoir includes worms, mayflies, midges, snalls, sponges, bryozoans, asiatic clams, mussels, and crayfish. Caddisflies and other flowing-water species are abundant in the upstream portion of the reservoir near Guntersville Dam. Historically, asiatic clams were abundant in Wheeler Reservoir, but a steady decline in clam populations has been documented during the past ten years.

\section{Musse1s}

In the past, several locations on Wheeler Reservoir provided habitat for large populations of mussels that supported a fairly important commercial fishery for their shells. These populations and associated fisheries have declined, however, presumably because of overharvesting and unfavorable environmental conditions. There have been no recent 
surveys of mussel resources in wheeler Reservoir. Existing information indicates these animals occur throughout much of the length of the reservoir. In the upstream part of the reservoir (essentialiy from Decatur upstream to Guntersville Dam), most mussels are found in the old river channe1. An almost continuous mussel bed in the Guntersville Dam tailwater (TRM 331-348.4) resembles the preimpouridment mussel faura. Many of the mussels found in the Guntersville tailwater were present before the reservoir was filled and very few young mussels have been found in this area. Downstream from Decatur, most mussels are found on the overbanks. These mussel stocks include many young individuals and a different mix of species from those found in the old river channel upstream. The former river channel in this downstream part of the reservoir is covered with silt and is, generally, unsuitable mussel habitat.

Four mussels (pink mucket, orange-foot pimpleback, rough pigtoe, and fanshe11) that occur in the reservoir are 1 isted as endangered both federally and by Alabama (note--the fanshell was 1 isted by the U.S. Fish and Wildife Service in 1990; its status by Alabama is unknown). A11 four species occur in the river channel upstream of Decatur. The pink mucket also occurs in the downstream reaches of the Paint Rock River near Wheeler Reservoir.

\section{Fish}

The Wheeler Reservoir fish community is diverse (81 species) and dominated by warmwater species. It includes important game and commercial warmwater species and also the coolwater species sauger and walleye. Domirant prey species are gizzard and threadfin shad.

The fish community of Wheler Reservoir is monitored annually by TVA by means of three cove rotenone surveys, which provide data on standing stock of game, rough, and forage species. Between 1969 and 1984, total standing stock averaged $20,871 \mathrm{fish}$ per acre weighing $635 \mathrm{lbs}$. More recent eatimates in 1985 and 1986 were $36,482 \mathrm{fish} / a c r e$ weighing $627 \mathrm{lbs} / \mathrm{acre}$ and $11,569 \mathrm{fish} / \mathrm{acre}$ welghing $547 \mathrm{lbs} / \mathrm{acre}$, respectively. 
Approximately 96 percent by number and 64 percent by weight were forage species (primarily gizzard shad). Game species comprised 4 percent of the total number and 11 percent of the total biomass. Estimates of abundance since 1969 have been cyclic, with a generally increasing trend over the 16-year period. Maximum abundance occurred in 1982. Below is a comparison of biomass of game, rough, and forage fishes in wheeler Reservoir with other mainstem Tennessee River reservoirs for the period 1949-1989.

\begin{tabular}{|c|c|c|c|c|c|c|}
\hline \multirow[b]{2}{*}{ Reservoir } & \multirow[b]{2}{*}{ Inclusive dates } & \multirow{2}{*}{$\begin{array}{c}\text { Number of } \\
\text { samples }\end{array}$} & \multicolumn{4}{|c|}{ Biomass (pounds per acre) } \\
\hline & & & Game & Rough & Forage & Total \\
\hline Kentucky & $1949-1982$ & 105 & 33 & 112 & 156 & 301 \\
\hline Pickwick & $1949-1987$ & 67 & 54 & 115 & 217 & 386 \\
\hline Wilson & $1949-1983$ & 29 & 53 & 132 & 149 & 334 \\
\hline Wheeler & $1949-1989$ & 96 & 110 & 205 & 361 & 676 \\
\hline Guntersville & $1949-1988$ & 93 & 68 & 82 & 141 & 291 \\
\hline Nickajack & $1972-1981$ & 22 & 91. & 41 & 88 & 220 \\
\hline Chickamauga & $1949-1989$ & 129 & 48 & 78 & 137 & 263 \\
\hline Watts Bar & $1949-1986$ & 73 & 28 & 115 & 89 & 232 \\
\hline Ft. Loudoun & $1949-1984$ & 33 & 43 & 79 & 157 & 279 \\
\hline
\end{tabular}

The snail darter, 1 isted as a threatened species both federally and by Alabama, is the only fish species of sensitive status likely to occur in Wheeler Reservoir. Snail darters have been found in the Paint Rock River. In other streams, young of this species are known to drift downstream into the Tennessee River during their first summer. Adult snail darters return to grave1 shoal.d in tributary streams each year to spawn.

The commerctal fishery in Wheeler Reservoir has been adversely affected for several years by significant levels of the pesticide DDT in fish tissues. Interstate sale of $\mathrm{fish}$ caught in wheeler Reservoir is banned by the Food and Drug Administration. However, the completion of DDT clean-up activities in Huntsville Spring Branch in 1988 is expected to resolve this problem within a few years.

Important sport fishes include largemouth bass, smallmouth bass, white crappie, bluegill, redear sunfish, white bass, yellow bass, and sauger. 
Also, Alabama has stocked striped bass and hybriu striped bass $x$ white bass in Wheeler Reservoir to provide additional sport fish species.

Largemouth bass. Fishermen consider this fishery excellent on Wheeler Reservoir as evidenced by the number of bass tournaments held from early spring through late fall. Area clubs and bass anglers correlate recent improvements in the fishery with the increase of aquatic vegetation. The milfoil around Decatur has become a "hot spot" for largemouth bass fishing. Data from TVA population studies since 1982 show a minimum of 40 harvestable bass per acre. In 1988 electrofishing samples taken by TVA, catch rates of. largemouth bass were more than twice the average historical catch rate, and relative weight analysis indicated that largemouth bass were heavier than expected for Tennessee River reservoirs. Analysis of the electroftshing data indicated a fatr largemouth bass fishery, as $28 \%$ of the fish collected were of quality size (fish $37 \%$ or more of the maximum attainable size). However, the proportion of larger fish was small, and no trophy-sized bass were collected in 1988 .

Smallmouth bass. Rocky bluffs and gravel bars abound in the lower end of Wheeler Reservoir, and the deep water and current adjacent to these areas provide prime smallmouth bass habitat. Recent TVA population studies have shown an increase in numbers of al1 sizes of smallmouth bass, but catch rates in electrofishing samples in 1988 were less than the historical average.

Panfish (white crappie, bluegil1, redear sunfish). Results of a crec1 survey in 1980 indicated that white crappie was the dominant species harvested from Wheeler Reservoir in terms of number (62\%) and biomass (54\%). Bluegi11 ranker second in number. Although catch rates of bluegill were less than the historical average, they were the most abundant sunfish in TVA electrofishing collections in 1988 , and $36 \%$ of those collected were quality fish. Catch rates of redear sunfish were more than twice the historical catch rate. Fishing for these species is heaviest from early spring through mid-summer, especially in the downstream half of the reservoir. Numerous tributaries, coves, and expansive overbank areas provide prime spawning and nursery areas for these species. 
Sauger." In recent years, sauger populations appear to have declined significantly in several TVA reservoirs, including wheeler Reservoir. TVA studies in wheeler Reservoir in 1987 and 1988 did not collect any sauger; they previously had been collected every year since 1969. Recent larval fish sampling in Wheeler Reservolr also suggests a decline in the population. The cause of the sauger decline is not known but is believed to be related to the drought that began in 1985. Water temperature fluctuations, flow rates and turbidity-al1 factors known to influence the success of sauger spawning--were atypical throughout the system during the drought. Fishing for this species is heaviest January through March in the Guntersville Dam tailwater and around tributary mouths in the upper end of the reservoir.

White and ye1low bass. Schools of white bass provide angling action spring through early fall. The yellow bass population in wheeler Reservoir is increasing. In 1988 electrofishing catches, the species was about five times more abundant than in historical catches.

A variety of wildlife is also associated with the reservoir. Wheeler National Wildife Refuge, the easternmost National Wildife Refuge on the lower Mississippi Flyway, is a wintering area for about 30,000 Canada geese and 50,000 to 70,000 ducks. Before establishment of the refuge in 1958 , the area wintered on $1 y$ 3,000 to 4,000 waterfuwl; the refuge now boasts the Southeast's highest concentrations of Canada geese. Although most waterfow1 that winter on wheeler Reservoir nest far to the north, many wood ducks and some mallards and black ducks nest on the refuge each spring. Although waterfow 1 are the most spectacular visitors, a wide variety of other wildlife is present. Many species of shorebirds stop briefly in early fall and again in the spring. Quail and nourning doves are numerous. In all, the list of birds around Wheeler Reservoir includes 304 species. 
In assessing the condition of state waters for the period 1986-1987, ADEM concluded that all or parts of Wheeler Reservoir did not support the designated uses. Point and nonpoint source, toxic and nontoxic pollutants were identified as causes of impairments.

Some important causes of impairments to the uses of Wheeler Reservoir aquatic resources include the following.

\begin{tabular}{|c|c|}
\hline Condition & Use(s) affected \\
\hline $\begin{array}{l}\text { Aquatic macrophyte } \\
\text { colonization }\end{array}$ & $\begin{array}{l}\text { Impairs or has the potential to } \\
\text { impair industrial water supply, } \\
\text { boating, shoreline usage, aesthetic } \\
\text { quality of the environment, and } \\
\text { power production. Associated } \\
\text { mosquito populations are a } \\
\text { nuisance. }\end{array}$ \\
\hline $\begin{array}{l}\text { Fish flesh contamination } \\
\text { with DDT }\end{array}$ & $\begin{array}{l}\text { Potential effect on human health } \\
\text { limits interstate commerce for } \\
\text { commercial catch and may impair the } \\
\text { sport fishing experience for some. }\end{array}$ \\
\hline Fecal coliform bacteria & $\begin{array}{l}\text { Potential for adverse effect on } \\
\text { human health may limit the use of } \\
\text { reservoir waters in certain areas } \\
\text { for swimming and other whole body } \\
\text { contact sports. }\end{array}$ \\
\hline Drought & $\begin{array}{l}\text { May have contributed to the recent } \\
\text { continuous decline of sauger } \\
\text { population. }\end{array}$ \\
\hline $\begin{array}{l}\text { Low flows with high organic } \\
\text { waste loading rates }\end{array}$ & $\begin{array}{l}\text { Intermittently results in lowered } \\
\text { anbient dissolved oxygen, which } \\
\text { potentially impairs wastewater } \\
\text { assimilation capacity of the } \\
\text { reservoir. }\end{array}$ \\
\hline High ambient water temperature & $\begin{array}{l}\text { May impair use of reservoir for } \\
\text { cooling water supply. }\end{array}$ \\
\hline $\begin{array}{l}\text { Commercial overharvesting of } \\
\text { mussel stocks }\end{array}$ & $\begin{array}{l}\text { Has depleted the large populations } \\
\text { of mussels once present in the } \\
\text { reservoir. }\end{array}$ \\
\hline
\end{tabular}




\section{SELECTED RESERVOIR MANAGEMENT AGENCIES}

Several agencies have a part in improving and protecting the hea1th and integrity of Wheeler Reservoir. These agencies investigate and monitor the reservoir and attempt to mitigate those conditions impairing its uses. A number of those agencies are listed below.

The Alabama Department of Environmental Management is the primary environmental regulatory agency in Alabama. It determines water use classifications, criteria, and standards and issues permits for wastewater discharges.

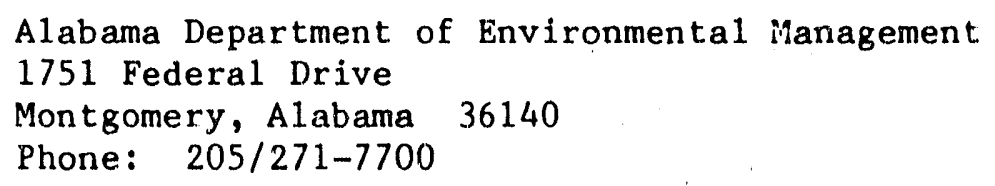

The Tennessee Valley Authority Water Resources Division manages the daily operations of Wheeler Reservoir, conducts water quality and aquatic resource monitoring and assessment programs, and develops plans for the protection and enhancement of water resources. The Land Resources Division manages TVA lands and recreation sites along the reservoir and develops reservoir land management plans.

Tennessee Valley Authority

Water Resources Division

Evans Building

Room 1W 141A

Knoxville, Tennessee 37902-1499

Phone: 615/632-6770
Tennessee Valley Authority Land Resources Division 170 office Service Annex Muscle Shoals, Alabama 35660 Phone: 205/386-2221

The Alabama Department of Conservation and Natural Resources is the $\mathrm{f}$ isheries management agency for Alabama. It is responsible for $\mathrm{fish}$ and game regulations and $f$ ish stocking.

\footnotetext{
Alabama Department of Conservation and Natural Resources 
The U.S. Department of Agriculture is responsible for soil conservation activities on farms. Various district conservationists located in county offices have responsibility for the wheeler Reservoir area.

The U.S. Environmental Protection Agency is responsible for the implementation of the Clean Water Act and oversees federa11y mandated programs managed by the states. The Region IV office in Atlanta, Georgia, is responsible for the Whecler Reservoir area and all of the southeastern United States.

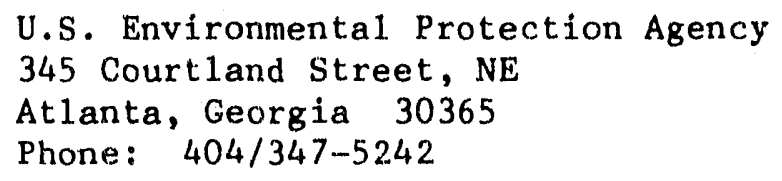

The U.S. Fish and Wildlife Service is responsible for ensuring the protection of fish and wildlife and their habitats during federally sponsored or permitted development activities and has responsibility for the identification of threatened and endangered species.

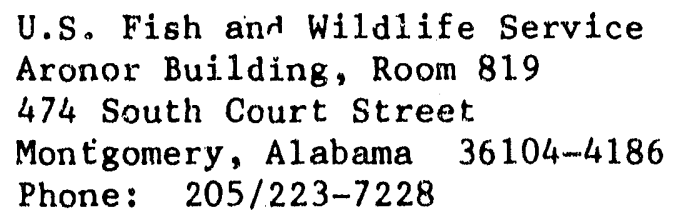


SELECTED REFERENCES

Alabama Department of Environmental Management. 1988. Water quality report to Congress for calendar years 1986 and 1987. Alabama Department of Environmental Management, Montgomery, Alabama.

Alabama Department of Environmental Management. 1989. Water quality assessment Alabama pub1ic lakes 1989. Alabama Department of Environmental Management, Montgomery, Alabama.

Buchanan, J. P. 1990. Thermal variance monitoring for Browns Ferry Nuclear Plant, Wheeler Reservoir, 1987-1989. Tennessee Valley Authority, Water Resources, Norris, Tennessee.

Burns, E. R., A. L. Bates, and D. H. Webb. 1989. Aquatic plant management program-- current status and seasonal workplan 1989. Aquatic Biology Department, Tennessee Valley Authority, Muscle Shoals, Alabana.

Cox, J. P. 1990. Surface water resources issues analysis: Wheeler Reservoir watershed region. Tennessee Valley Authority, Water Resources, Chat tanooga, Tennessee.

Heve1, K. W. 1988. Survey of the population dynamics of sauger (Stizostedion canadense) in Chickamauga Reservoir, Tennessee 1986 and 1987. Tennessee Valley Authority, Office of Natural Resources and Economic Development, Division of Services and Field Operations, Norris, Tennessee.

Hickman, G. D. and R. B. Fitz. 1978, A report on the ecology and conservation of the snail darter (Percina tanasi Etnier) 1.975-1977. Tennessee Valley Authority, Division of Forestry, Fisheries, and Wildife Development, Norris, Tennessee.

Isom, B. 1969. The mussel resource of the Tennessee River. Malacologia $7: 397-425$.

Placke, J. 1983. Trophic status evaluation of TVA reservoirs. Tennessee Valley Authority, Water Resources, Chat tanooga, Tennessee. TVA/ONR/WR-83/7.

Scruggs, G. 1960. Status of fresh-water mussel stocks in the Tennessee River. U. S. Fish and Wildlife Service, Special Report, Fisheries No. $370: 1-41$.

Tennessee Valley Authority. 1989. TVA reservoir biomonitoring program -Fish populations results of 1988 survey. Tennessee Valley Authority, System Engineering, Knoxville, Tennessee.

Tennessee Valley Authority. 1990. Draft environmental impact statement: Tennessee River and reservoir system operation and planning review. Tennessee Valley Authority, TVA/RDG/EQS-90/1. 
This work was funded by federal appropriations to the Tennessee Valley Authority (TVA) for water resources management. This report was prepared by members of a project team of the Water Resources Division of TVA with other TVA statf assisting.

Your comments and suggestions are important to us! They help us better meet the information needs of reservoir users. Comments, suggestions, and requests for additional copies of this report should be directed to:

\author{
Larry R. C1ark \\ Water Quality Department \\ Tennessee Valley Authority \\ Haney Building, Room 2 S $270 \mathrm{C}$ \\ 311 Broad Street \\ Chat tanooga, Tennessee 37402-2801 \\ Phone: (615) 751-7331
}

TVA is an equal opportunity and affirmative action employex. TVA also ensures that the benefits of programs receiving TVA financial assistance are available to all eligible persons regardless of race, color, sex, national origin, handicap, or age. 

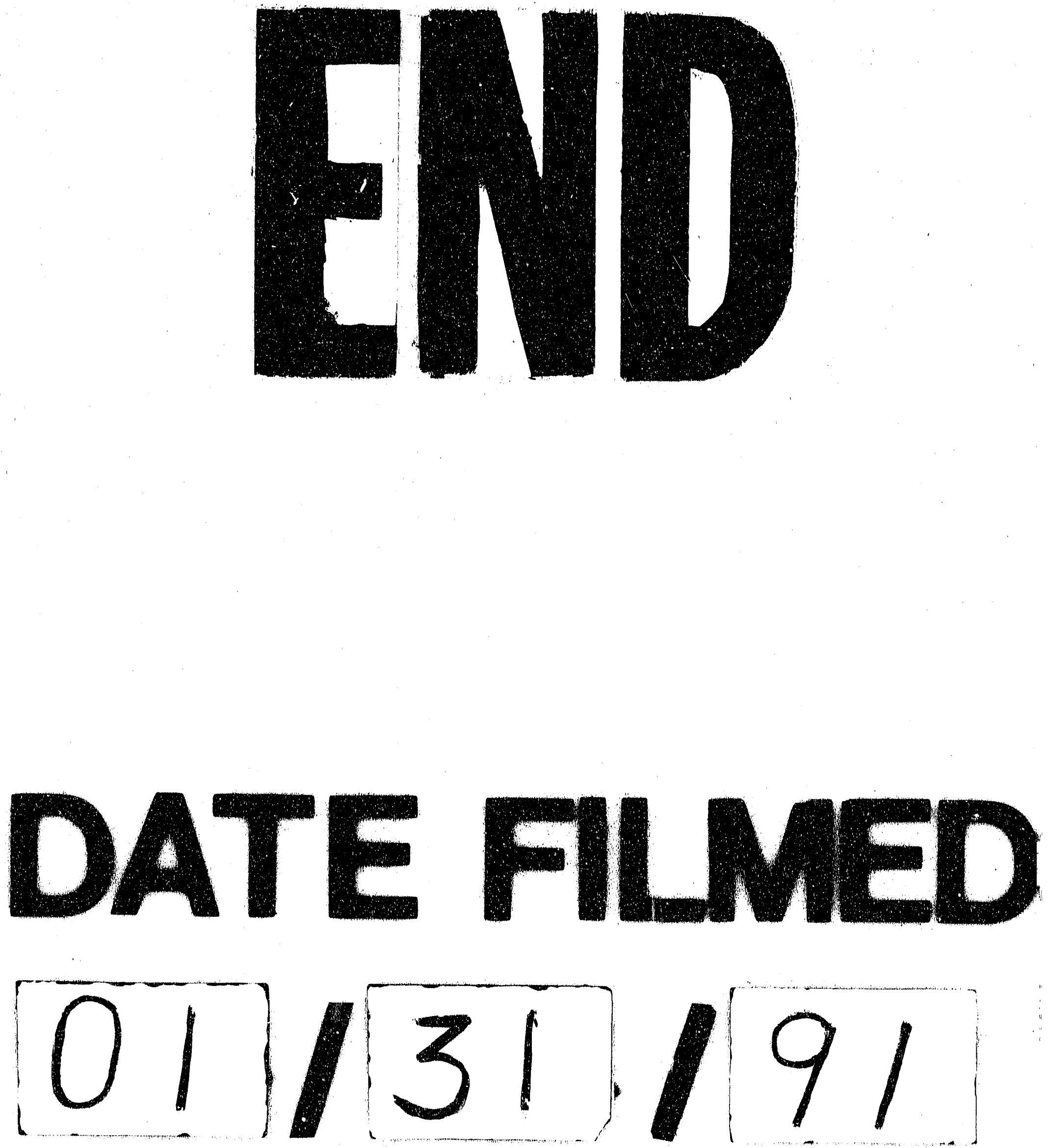
